\title{
Fen Bilimleri Öğretmenlerinin Proje Çalışmalarına İlişsin Algılarının ve Görüşlerinin İncelenmesi
}

\author{
Examining the Perceptions and Views of Science Teachers on Project \\ Studies \\ Oğuzhan NACAROĞLU*, Fatma MUTLU** \\ • Geliş Tarihi: $30.06 .2019 \bullet$ Kabul Tarihi: 29.12.2019 • Çevrimiçi Yayın Tarihi: 24.02.2020
}

\section{Öz}

$\mathrm{Bu}$ araştırmada fen bilimleri öğretmenlerinin proje algısı ile rehberlik ettikleri proje çalışmalarına ilişkin görüşlerinin incelenmesi amaçlanmıştır. Araştırmada nitel araştırma yöntemi desenlerinden durum çalışması kullanılmış olup 2018-2019 eğitim öğretim yılında Malatya ilinin farklı ilçe ve okullarında görevlerine devam eden 82 fen bilimleri öğretmeni ile çalışma yürütülmüştür. Çalışma grubunun belirlenmesinde amaçlı örnekleme yöntemlerinden ölçüt örnekleme yöntemi tercih edilmiştir. Araştırmada veri toplama aracı olarak metafor formu ile yazılı görüş soruları formu kullanılmıştır. Verilerin analizinde içerik analizi yürütülmüştür. Çalışmaya katılan 82 fen bilimleri öğretmeni tarafından "proje" kavramına ilişkin 68 adet metafor üretildiği, metaforların ise "öğrenmeye yardımcı" kategorisi altında yoğunlaştığı belirlenmiştir. Bununla birlikte bazı öğretmen adaylarının $(\% 17,07)$ metafor üretmede zorlandıkları tespit edilmiş ve bu durum ise öğretmenlerin proje kavramına ilişkin algılarının yeterli düzeyde olmadığını göstermiştir. Aynı zamanda öğretmenlerin çoğu proje çalışmalarının, öğrencilerin merak ve araştırma duygusunu geliştirerek özgün fikirler üretmesine yardımcı olduğunu belirtmişlerdir. Fen bilimleri öğretmenleri proje çalışmalarında en çok malzemeye ve veri toplama aracına ulaşma ile öğrencilerin süreyi iyi değerlendirememe noktasında problem yaşadıklarını $(\% 45,12)$; bu problemlerin çözümüne yönelik ise proje atölyelerinin kurulmasını ve öğrencilere proje süresince rehberlik edilmesini önermişlerdir. Elde edilen veriler ışı̆̆ında gerekli öneriler yapılmıştır.

Anahtar sözcükler: fen bilimleri öğretmeni, proje algısı, proje çalışmalarına yönelik görüşler.

Atıf:

Nacaroğlu, O., ve Mutlu, F. (2020). Fen bilimleri öğretmenlerinin proje çalışmalarına ilişkin algılarının ve görüşlerinin incelenmesi. Pamukkale Üniversitesi Eğitim Fakültesi Dergisi, 50, 247268.doi:10.9779/pauefd.584534

\footnotetext{
*MEB, Malatya Bilim ve Sanat Merkezi, Fen Bilimleri Öğretmeni, ORCID: 0000-0001-8516-9152, onacaroglu44@gmail.com

${ }^{* * *}$ Doç. Dr., İnönü Üniversitesi, Fen bilgisi Öğretmenliği, ORCID: 0000-0002-8643-1236, fatma.mutlu @inonu.edu.tr
} 


\begin{abstract}
In the study, it is aimed to examine the project perceptions of science teachers and their views on project studies they guide. The study was conducted with 82 science teachers working in different districts and schools of the province of Malatya in the school year of 2018-2019 by using case study, which is among qualitative research method designs. The sample group was determined using the criterion sampling method, which is among purposeful sampling methods. In the study a metaphor form and a written view questions form were used as the data collection form. The content analysis was conducted in the analysis of the data. It was determined that the 82 science teachers who participated in the study produced 68 metaphors concerning the concept of "project" and the metaphors intensified under the category of "support in learning". In addition, it was determined that some of the preservice teachers $(17.07 \%)$ had a difficulty in producing metaphors, which shows that the teachers did not have sufficient perceptions concerning the concept of project. Also, majority of the teachers indicated that project studies developed students' sense of curiosity and investigation and helped them produce distinctive ideas. The science teachers stated that they faced the greatest problem at the point of accessing to materials and data collection tools and failing to use the time by students well in project studies (45.12\%). In order to solve these problems, they recommended establishing project workshops and guiding students throughout the project. In the light of the data acquired, necessary recommendations were made.
\end{abstract}

Keywords: Science teacher, project perception, views on project studies

Cited:

Nacaroğlu, O., \& Mutlu, F. (2020). Examining the perceptions and views of science teachers on project studies. Pamukkale Üniversitesi Eğitim Fakültesi Dergisi, 50, 247-268. doi:10.9779/pauefd.584534 


\section{Giriş}

Eğitim ortamlarında uzun yıllar boyunca bilginin öğretilmesi benimsenmiş ve öğrenmelerle birlikte elde edilen sonuçlar dikkate alınmıştır (Zelyurt ve Özbek, 2018). Ancak bilgiden ziyade bilginin içselleştirilmesinin önemli olduğu günümüzde eğitim alanında yeniliklere gidilmiş ve bireylere 21. yüzyıl becerilerinin kazandırılması amaçlanmıştır (Allison, 2018; Velegol ve Zappe, 2015). 21. yüzyıl becerilerinin ortak bir tanımı olmamakla birlikte genel olarak "öğrenme ve yenilik", "kariyer ve yaşam" ile "dijital okuryazarlık" becerilerini ifade etmektedir (Trilling ve Fadel, 2009). Ayrıca 21. yüzyıl becerileri; bilginin harmanlanmasını, çalışma alanındaki yetkinlikleri, günlük ve çalışma anında yaşanan problemleri çözme ve başarıya ulaşma becerilerini de içermektedir (Ledward ve Hirata, 2011). Dolayısıyla temel ve uygulamalı becerileri içeren ve yeni sanayi devrimine bireylerin uyum sağlayabilmeleri için sahip olmaları gereken özellikleri ifade eden 21. yüzy1l becerileri birçok alt temadan meydana gelmektedir (Keleşoğlu ve Kalayc1, 2017).

21. Yüzyıl Beceri Ortaklığı (2009) 21. yüzyıl becerilerini; yaşam, kariyer, bilgi, teknoloji, medya, öğrenme, yenilenme becerileri temaları altında toplamıştır. $\mathrm{Bu}$ ana temalar altında ise; yaratıcılık, eleştirel düşünme, yenilik, adapte olabilirlik, işbirliği, problem çözme, iletişim, medya, bilgi ve teknoloji okuryazarlı̆̆ 1 , kendini yönetme, esneklik, girişkenlik, liderlik, sosyal ve kültürlerarası beceriler, sorumluluk, üretkenlik gibi alt boyutlara yer verilmiştir (Partnership for 21st Century Skills, 2009). Bu becerilerin bireylere kazandırmasına yönelik yürütülen eğitim faaliyetleri yapılandırmacı kuramın daha fazla benimsenmesini (Okumuş ve Doymuş, 2018) ve tüm eğitim alanlarında yeniliklerin ve düzenlenmelerin yapılmasını zorunlu kılmıştır (Atabek-Yiğit ve Balkan-Kıyıcı, 2018). Bu alanlardan birisi de ölçme ve değerlendirme olup geleneksel ölçme ve değerlendirme yöntemlerine ek olarak alternatif ölçme ve değerlendirme uygulamaları da eğitim faaliyetlerinde yerini almıştır (Gömleksiz, Sinan ve Demir, 2010).

Alternatif ölçme ve değerlendirme yöntemleri, öğrencilere beceri, bilgi ve tutumlarını sergileyebilecekleri çoklu değerlendirme ortamları sunarak (Arı, 2010; MEB, 2018) öğrencilerin düşüncelerini rahat bir şekilde ifade etmelerine (Yıldız ve Uyanık, 2004), duyuşsal ve üst düzey becerilerin ölçülmesine de yardımcı olmaktadır (Hodges, Lamb, Brown ve Foy, 2005). Alternatif ölçme ve değerlendirme yöntem ve tekniklerine; öz değerlendirme, öğrenci ürün dosyaları, akran değerlendirme, kontrol listeleri, dereceleme ölçekleri, yapılandırılmış grid, poster, performans ve proje çalışmaları örnek verilebilir (Egodawatte, 2010). Bu alternatif ölçme ve değerlendirme yöntemlerinden birisi de öğrencilere yeni bilgilere ulaşma ve bu bilgiyi sunma firsatı veren, günlük hayatta yer alan problemlerin çözümünde eleştirel ve yaratıcı düşünme becerileri kazandıran proje çalışmalarıdır. Günümüz eğitim sisteminde önemli bir yere sahip olan proje çalışmalarının yoğun bir şekilde kullanıldığ dersi gelmektedir (Sokur, 2018).

Ülkemizde fen bilimleri öğretim programında öğrencinin kendi öğrenmesinden sorumlu olduğu, işbirliğine, araştırmaya, sorgulamaya ve bilginin transfer edilmesine dayalı ögretim stratejileri temel alınmıştır (Evmez, 2018). Bu kapsamda öğrencilere 21. yüzyıl becerilerini kazandırmayı hedefleyen fen bilimleri dersinde proje çalışmalarının yürütülmesi öngörülmektedir (MEB, 2018). Çünkü proje çalışmaları ifade edilen becerilerin öğrencilere kazandırılması için etkili ve alternatif ölçme değerlendirme yöntemlerinden birisidir (Fallik, 
Eylon ve Rosenfeld, 2008). Bununla birlikte öğrencileri sürece dahil ederek kalıcı öğrenmelerin gerçekleştirilmesinde büyük bir öneme sahip olan proje çalışmalarında öğretmenlere büyük görevler düşmektedir. Ancak öğretmenlerin proje görevleri süresince birçok zorluklarla karşılaştıkları görülmektedir (Bayat ve Şentürk, 2015). Öğretmenlerin; öğrenciye uygun proje görevi vermede, proje sürecini yönetmede (Nacaroğlu ve Mutlu, 2018), öğrenci gruplarının oluşturulmasında, projelerin raporlaştırılmasında, öğrenciye rehberlikte, proje görevini değerlendirmede sorun yaşadıkları birçok çalışmada ortaya konmuştur (Akbaş ve Gençtürk, 2013; Öztuna-Kaplan ve Diker-Coşkun, 2012; Uzal, Erdem ve Ersoy, 2012). Bu problemlerin çözümüne yönelik ise öğretmenlere gerekli eğitimlerin verilmesi önerilmektedir (Neukom, 2000; Zimbicki, 2007). Bununla birlikte alan yazın incelendiğinde fen bilimleri ögretmenlerinin proje çalışmalarına yönelik algısının nasıl olduğunu inceleyen bir çalışmaya rastlanmamıştır. Dolayısıyla yoğun bir şekilde proje çalışmalarının yürütüldüğü fen bilimleri dersini veren öğretmenlerin proje çalışmalarını sağlıklı yürütebilmeleri için öncelikle proje çalışmalarına yönelik algılarının tespiti, bu çalı̧̧manın bir kısmını oluşturmaktadır. Öğretmenlerin proje çalışmalarına yönelik algılarının tespitinde en iyi yollardan birisi sahip oldukları metaforlardır (Carpenter, 2008).

Metaforlar, anlam bakımından benzerlik gösteren iki yapının birlikte kullanılmasını ifade eder (Gültekin, 2013) ve kişilerin belli bir olguya yükledikleri anlamı ortaya koymada etkilidirler. Ayrıca metaforlar, özellikle öğretmenlerin ve öğrencilerin ifade etmek istedikleri şeyleri anlaşılır ve kısa bir şekilde açıklamalarına ve düşüncelerini özgür bir şekilde belirtmelerine firsat verirler (Tompkins ve Lawley, 2002). Dolayısıyla bu çalışmanın ilk kısmında fen bilimleri öğretmenlerinin, öğrencilere 21. yüzyıl becerilerini ve farklı bilimsel bakış açısı (Önen-Öztürk ve Ağlarc1, 2019) kazandırmada etkili yollardan birisi olan proje çalışmalarına yönelik metaforik algılarını incelemek amaçlanmıştır. Diğer taraftan fen bilimleri öğretmenlerinin proje çalışmaları esnasında yaşadığı problemlerin tespiti ve bu problemlere yönelik öğretmenlerin çözüm önerilerinin değerlendirildiği çalışmaların çok az olduğu da görülmektedir (Çoruhlu, Er Nas ve Çepni, 2009). Çalışmanın diğer kısmında ise fen bilimleri öğretmenlerinin rehberlik ettikleri proje çalışmalarının yararlarına, proje çalışmalarında karşılaştıkları güçlüklere ve çözüm önerilerine yönelik görüşleri incelenmiştir. Dolayısıyla yürütülen bu çalışmada, fen bilimleri öğretmenlerinin proje algıları ile proje çalışmalarında karşılaştıkları problemlere ve bu problemlerin çözümüne yönelik önerilerinin nasıl olduğunun incelenmesi amaçlanmıştır. Elde edilen sonuçların; derslerinde yoğun bir şekilde proje çalışmalarını kullanan fen bilimleri ögretmenlerine, fen bilimleri alanında proje çalışmaları yapmak isteyen öğrencilere ve bu alanda çalışan araştırmacılara yardımcı olacağı düşünülmektedir. Buradan hareketle aşağıda ifade edilen problemlere cevap aranmıştır:

1. Fen bilimleri öğretmenlerinin proje kavramına ilişkin ifade ettikleri metaforlar nelerdir? $\mathrm{Bu}$ metaforlar ortak özellikler bakımından hangi kavramsal kategoriler altında ifade edilebilir?

2. Fen bilimleri öğretmenlerinin proje çalışmalarının yararlarına ilişkin görüşleri nelerdir?

3. Fen bilimleri öğretmenlerinin proje çalışmaları sürecinde karşılaştıkları problemler nelerdir?

4. Fen bilimleri öğretmenlerinin proje çalışmaları sürecinde karşılaştıkları problemlere ilişkin çözüm önerileri nelerdir? 


\section{Yöntem}

\section{Araştırma Deseni}

$\mathrm{Bu}$ araştırma, nitel araştırma yöntemi desenlerinden "durum çalışması" kullanılarak yürütülmüştür. Durum çalışması; güncel bir olgu ya da olayı kendi gerçek yaşam çerçevesi içinde çalışan ve araştırmacılara olgu ve olayın ayrıntılı incelemesine imkan veren nitel araştırma desenidir (Yıldırım ve Şimşek, 2013). Bu çalışmada da fen bilimleri öğretmenlerinin proje algıları ve proje çalışmaları sürecinde karşılaştıkları problemler ve çözüm önerileri araştırılmak istendiğinden durum çalışması tercih edilmiştir.

\section{Çalışma Grubu}

$\mathrm{Bu}$ araştırmanın çalışma grubunu, 2018-2019 öğretim döneminde Malatya ilinin farklı ilçe ve okullarında görev yapan 82 fen bilimleri öğretmeni oluşturmaktadır. Araştırmanın çalışma grubunun belirlenmesinde amaçlı örnekleme yöntemlerinden ölçüt örnekleme yöntemi tercih edilmiştir. Ölçüt örneklemede, örneklem birimleri belli özellikleri bünyesinde barındıran kişiler, nesneler ve olaylardan meydana gelir (Büyüköztürk vd., 2012). Bu kapsamda araştırmanın çalışma grubu belirlenirken; okullarında yürütülen fen bilimleri proje çalışmalarında danışmanlık görevini üstlenmiş ve proje çalışmalarına yönelik belli eğitimi ve tecrübesi olan fen bilimleri öğretmenleri tercih edildiğinden çalışma grubunun belirlenmesinde ölçüt örnekleme yöntemi kullanılmıştır. Araştırmaya katılan öğretmenlere yönelik demografik bilgiler Tablo 1'de verilmiştir:

Tablo 1. Katılımcılara ait Demografik Bilgiler

\begin{tabular}{|c|c|c|c|c|c|}
\hline Demografik özellikler & f & $\%$ & & f & $\%$ \\
\hline Cinsiyet & & & Mesleki deneyim & & \\
\hline Kadın & 47 & 57,31 & $1-10$ y1l & 22 & 27,83 \\
\hline Erkek & 35 & 42,69 & $11-20$ y1l & 40 & 47,78 \\
\hline$\underline{\text { Yas }}$ & & & 21 ve yukarısı & 20 & 24,39 \\
\hline $20-30$ & 13 & 15,85 & Öğrenim Durumu & & \\
\hline $31-40$ & 39 & 47,56 & Lisans & 73 & 89,02 \\
\hline 41 ve yukarıs1 & 30 & 36,59 & Yüksek Lisans & 9 & 10,98 \\
\hline
\end{tabular}

Tablo 1 incelendiğinde araştırmada yer alan katılımcıların \%57,31'i kadın, \%42,69’u erkek bireylerden oluştuğu görülmektedir. Bununla birlikte katılımcıların 22'si 1-10 yıl arası, 40'1 11- 20 yıl arası, 20'si ise 21 yıl ve daha fazla süre fen bilimleri öğretmeni olarak görev yapmışlardır.

\section{Veri Toplama Araçları}

$\mathrm{Bu}$ araştırmada veri toplama aracı olarak metafor formu ile yazılı görüş soruları formu kullanılmıştır. Araştırmada kullanılan form iki kısımdan oluşmaktadır. İlk kısımda katılımcılara ait demografik bilgiler, ikinci kısımda ise katılımcıların proje algılarını tespit etmek için metafor cümlesinden ve proje çalışmalarına yönelik görüşlerini aktarmaları için açık uçlu üç adet sorudan oluşmaktadır. Bu kapsamda öncelikle katılımcılara "Proje ......................... 
.gibidir/benzemektedir.Çünkü......................................” cümlesini tamamlamaları istenmiştir. Daha sonra "Okulunuzda rehberliğini yaptığınız proje çalışmalarının (ödevlerinin) yararları hakkında düşünceleriniz nelerdir? Öğrenci, öğrenme alanı ve öğretmen açısından değerlendiriniz.", "Proje çalışmalarında nasıl problemlerle karşılaşıyorsunuz?", "Karşılaştı̆̆ınız problemlere yönelik çözüm öneriniz nelerdir?” sorularını cevaplamaları istenmiştir. Öğretmenlerin proje kavramına yönelik algıları proje çalışmalarını sağlıklı yürütebilmeleri noktasında önemli olduğundan metafor formu ile proje çalışmalarına yönelik açı uçlu sorular bir arada verilmiştir. Ayrıca form, alanında uzman iki fen eğitimcisinin görüşlerine sunulmuştur. Veri toplanması sürecinde öğretmenler ile yüz yüze iletişime geçilmiş ve öğretmenlerin formu rahat bir şekilde doldurmaları için sessiz bir ortam tercih edilmiştir.

\section{Verilerin Analizi}

Verilerin analizinde içerik analizi yöntemi kullanılmıştır. İçerik analizi, elde edilen verilerin kategorilendirilmesi, bu kategorilerin kodlamalarla daha küçük yapılar halinde sistematik bir şekilde ifade edilmesidir (Büyüköztürk vd., 2012). İlk olarak metaforların analizinde; kodlama ve ayıklama, örnek metafor derleme, kategori geliştirme, geçerlilik ve güvenilirlik çalışması ve verilerin bilgisayar ortamına aktarılması aşamalarının izlendiği tespit edilmiş ve bu kapsamda analizler yürütülmüştür (Özbuğutu, 2018). Bunun için araştırmanın ilk kısmını oluşturan fen bilimleri öğretmenlerinin proje kavramına ilişkin ürettikleri metaforlar incelenmiş ve uygun olmayan metaforlar elenmiştir (Ekici, 2016). Her bir forma gizlilik kapsamında K1, K2, K3...K82 şeklinde numaralar verilmiştir. Metaforlar tekrar incelenerek bulgular kısmında metaforu temsil edecek örnek metaforlar belirlenmiştir. Metafor ve metaforu gerekçelendiren cümleler tek tek incelenerek metaforlar kategoriler altında ifade edilmiştir. Bu kapsamda; ögrenmeye yardımcl, emek harcama, tasarım, süreç, mutluluk kaynă̆ı ve gereksiz/faydasız şeklinde altı kategori tespit edilmiştir. Ayrıca yürütülen analiz sürecinde güvenirliği sağlamak adına metaforlar ve yer aldıkları kategorilere yönelik alanında uzman fen eğitimcisinin görüşlerine başvurulmuştur (Miles ve Hubermann, 1994). Daha sonra her bir metafor bilgisayar ortamına aktarılmış ve metaforlara ait frekans değerleri hesaplanmıştır. Araştırmaya katılan fen bilimleri öğretmenlerinin proje çalışmalarına ilişkin görüşlerini derinlemesine incelemek için açı uçlu sorulara verilen cevaplara içerik analizi yapılmıştır. Bu kapsamda her bir soruya verilen cevaplar incelenmiş olup kodlar ve kategoriler altında katılımcı görüşleri ifade edilmiştir. Her bir kod ve kategoriye yönelik elde edilen veriler için uzman görüşü alınmıştır. Bununla birlikte bulgular kısmında her bir koda yönelik frekans değerleri ve o kodu ifade eden örnek katılımcı cümlelerine yer verilmiştir. Belirlenen koda yönelik örnek katılımcı görüşleri bulgular kısmında doğrudan aktarılmıştır.

\section{Bulgular}

\section{Fen Bilimleri Öğretmenlerinin Proje Kavramına İlişkin Metaforik Algıları}

$\mathrm{Bu}$ çalışmaya katılan 82 fen bilimleri öğretmeni tarafından proje kavramına ilişkin 68 adet metafor ürettikleri belirlenmiştir. Bu metaforlar ve her bir metaforun öğretmen adayları tarafindan tekrarlanma sayısı Tablo 2'de gösterilmiştir: 
Tablo 2. Proje Kavramına İlişskin Öğretmen Metaforları

\begin{tabular}{clcccc}
\hline Metafor & f & Metafor & f & Metafor & f \\
\hline Gelişim & 3 & Yap/öğren & 1 & Tecrübe & 1 \\
Yemek & 3 & Ayna & 1 & Seyirci Jokeri & 1 \\
Tasarım & 3 & Tekerleğin icadı & 1 & Yemek yemek & 1 \\
Takım çalışması & 3 & Yazılı & 1 & Kanunun açıklanması & 1 \\
Hayal gücü & 2 & Çarşı & 1 & Beceri & 1 \\
Hayat & 2 & Nano teknoloji & 1 & Düş & 1 \\
Yeni Ürün & 2 & Doğa & 1 & Plan & 1 \\
Çiçek & 2 & Okul & 1 & Araştırma & 1 \\
Sanat & 2 & Küresel farkındalık & 1 & Insan & 1 \\
Üretim & 2 & Betimleme & 1 & Yillı̈ ödev & 1 \\
Tohum & 1 & Sinav & 1 & Yaşamın kolaylaşması & 1 \\
Angarya & 1 & Pratik & 1 & Matematik problemi & 1 \\
Ürün güncellemesi & 1 & Öğretmen & 1 & Sabun köpüğ̈̈ & 1 \\
Yolculuk & 1 & Gelecek & 1 & Yapboz & 1 \\
Sonsuz olasılıklar & 1 & İlim dünyasına adım & 1 & Hayal & 1 \\
Çocuk & 1 & Özgün çalışma & 1 & Kaliteli yaşam & 1 \\
Eser & 1 & Güneş & 1 & Araştırma ödevi & 1 \\
Uygulamalı öğrenme & 1 & Öğrenme & 1 & Üretkenlik & 1 \\
\hline
\end{tabular}

Tablo 2 incelendiğinde fen bilgisi öğretmen adaylarının 68 metafor ürettikleri görülmektedir. Bu metaforlardan; gelişim, yemek, tasarım ve takım çalışması metaforlarının üç, hayal gücü, hayat, yeni ürün, çiçek, sanat ve üretim metaforlarının iki, belirlenen diğer metaforların ise katılımcılar tarafından bir kez tekrar edildiği tespit edilmiştir.

\section{Metaforların Kategorilendirilmesi}

Araştırmada "Fen bilimleri ögretmenlerinin ürettikleri metaforlar ortak özellikler bakımından hangi kavramsal kategoriler altında ifade edilebilir?" sorusuna cevap aranmıştır. İçerik analizi sonucu fen bilimleri öğretmenleri tarafından belirlenen ve araştırmaya dahil edilen metaforlar "ögrenmeye yardımcı, emek harcama, tasarım, süreç, mutluluk kaynağı ve gereksiz/faydasız" şeklinde altı kavramsal kategori altında toplanmıştır. Bu kategorilerde yer alan metafor sayıları, yüzdeleri ve kavramsal kategorilere uygun örnek metafor cümleleri Tablo 3 'te verilmiştir:

Tablo 3. Proje Kavramına İlişkin Metaforların Kavramsal Kategorileri

\begin{tabular}{|c|c|c|c|}
\hline \multirow{2}{*}{ Kategoriler } & \multicolumn{3}{|r|}{ Metaforlar } \\
\hline & $\mathbf{f}$ & $\%$ & Örnek metafor \\
\hline Öğrenmeye yardımcı & 21 & 30,89 & $\begin{array}{l}\text { Proje öğretmen gibidir. Çünkü öğrencilerin bilgi sahibi } \\
\text { olması için verilir. }\end{array}$ \\
\hline Emek harcama & 13 & 19,12 & $\begin{array}{l}\text { Proje tohum gibidir. Çünkü emek verirsiniz, sabretmeyi } \\
\text { öğrenirsiniz ve filizlendiğini görünce mutlu olursunuz. }\end{array}$ \\
\hline Tasarım & 12 & 17,65 & $\begin{array}{l}\text { Proje hayal gücü gibidir. Çünkü özgün, kendince yeni } \\
\text { fikirler ve ürünler ortaya koyarsın. }\end{array}$ \\
\hline Süreç & 10 & 14,70 & $\begin{array}{l}\text { Proje çiçek gibidir. Çünkü bir çiçeği büyümesi gibi her } \\
\text { aşamasında belli aşamalar vardır. }\end{array}$ \\
\hline Mutluluk kaynağı & 6 & 8,82 & $\begin{array}{l}\text { Proje yemek gibidir. Çünkü hazırlarken bile her anında } \\
\text { sonuca ulaşmak için mutluluk yaşarsın. }\end{array}$ \\
\hline Gereksiz/Faydasız & 6 & 8,82 & $\begin{array}{l}\text { Proje angarya gibidir. Çünkü öğrencilerin önemsemediği, } \\
\text { sadece e-okula not girişinin yapılması için bir şeydir. }\end{array}$ \\
\hline
\end{tabular}

Tablo 3 incelendiğinde fen bilimleri öğretmenlerinin; "Öğrenmeye yardımcl” kategorisi altında en çok metafor ürettikleri $(\% 30,89)$, "Gereksiz/Faydasız" ve "Mutluluk kaynă̆ı" 
kategorileri altında ise en az metafor ürettikleri $(\% 8,82)$ görülmektedir. Farklı uzmanların incelemeleri sonucu kategorilere yerleştirilen öğrenci metaforları ve bu metaforlara yönelik örnekler sırasıyla verilmiştir:

\section{Öğrenmeye yardımcı olması yönünden proje çalışması}

Öğrenmeye yardımcı kategorisi altında 21 metafor belirlenmiştir. Bu metaforlardan gelişim ve takım çalışması metaforu iki kez tekrarlanırken, diğer metaforlar katılımcılar tarafından birer kez ifade edilmiştir. Bu kategori altında yer alan öğretmen metaforları Tablo 4'te verilmiştir:

Tablo 4. “Öğrenmeye yardımcı” Kategorisine Ait Öğretmen Metaforları

\begin{tabular}{|c|c|c|c|c|c|}
\hline \multicolumn{6}{|c|}{ Öğrenmeye yardımcı } \\
\hline Metafor & $\mathbf{f}$ & Metafor & $\mathbf{f}$ & Metafor & $\mathbf{f}$ \\
\hline Gelişim & 2 & Öğretmen & 1 & Tecrübe & 1 \\
\hline Takım çalıșması & 2 & Pratik & 1 & Ürün güncellemesi & 1 \\
\hline Araştırma & 1 & Okul & 1 & Çocuk & 1 \\
\hline Güneş & 1 & Çarş1 & 1 & Tasarım & 1 \\
\hline Uygulamalı öğrenme & 1 & Beceri & 1 & Kanunun açıklanması & 1 \\
\hline $\begin{array}{l}\text { Üretkenlik } \\
\text { Sanat }\end{array}$ & 1 & Gelişim & 1 & İnsan & 1 \\
\hline
\end{tabular}

Öğrenmeye yardımcı kategorisine ait örnek öğretmen metaforları aşağıda verilmiştir:

Proje güneş gibidir. Çünkü projeler öğrencilere ışık yayar ve gerçekleri ögretir (K4),

Proje üretkenlik gibidir. Çünkü kişinin yaratıcıllğını ön plana çıkarır ve yeni bilgilere ulaşmasina firsat verir (K6),

Proje kanunun açıklanması gibidir. Çünkü yapılan kanunun iyi anlaşılmasını sağlar (K11),

Proje okul gibidir. Çünkü yeni ve farklı ögrenme imkanları sunar (K14),

Proje takım çalışması gibidir. Çünkü herkesin kendi fikirlerini tek bir şeyin içine koymasına ve başkalarının neler düşündüklerini görebilme firsatı verir (K18),

Proje insan gibidir. Çünkü konu üstünde çalıştıkça keşfedilmeyen yeni bilinmeyenler ortaya çıkar (K19).

\section{Emek harcama yönünden proje çalışması}

Emek harcama kategorisi altında öğretmenlerin 13 metafor ürettikleri belirlenmiştir. Bu kapsamda öğretmenler projelerin sağlıklı bir şekilde yürütülebilmesi için belli bir çaba gösterilmesi gerektiğine vurgu yaptıkları görülmektedir. Bu kategori altında yer alan öğretmen metaforları Tablo 5'te verilmiştir:

Tablo 5. "Emek harcama" Kategorisine Ait Öğretmen Metaforları

\begin{tabular}{cccccc}
\hline & \multicolumn{5}{c}{ Emek harcama } \\
\hline Metafor & f & Metafor & f & Metafor & f \\
\hline Kaliteli yaşam & 1 & Takım çalışması & 1 & Eser & 1 \\
Hayal & 1 & Doğa & 1 & Özgün çalışma & 1 \\
Hayat & 1 & Hayal gücü & 1 & Küresel farkındalık & 1 \\
Yemek yemek & 1 & Tohum & 1 & Betimleme & 1 \\
Sınav & 1 & & & \\
\hline
\end{tabular}

"Emek harcama" kategorisine ait örnek öğretmen metaforları aşağıda verilmiştir:

Proje hayal gücü gibidir. Çünkü hayal edebildiğin kadar proje yapabilirsin (K22), 
Proje sınav gibidir. Çünkü çalışmak gerekir (K27),

Proje hayat gibidir. Çünkü hayatın her alanında yaşantının güncellenmesi gerek (K29),

Proje hayat gibidir. Çünkü gerçekleştirebilmek için çalışmak gerekir (K30),

Proje kaliteli yaşam gibidir. Çünkü merakla başlayan proje çalışmaları kaliteli olabilmesi için çalışma yapmak gerekir (K34),

\section{Tasarım yönünden proje çalışması}

Tasarım kategorisi altında öğretmenlerin 12 metafor ürettikleri tespit edilmiştir. Öğretmenler bu kategori altında proje çalışmalarının bir ürün tasarımı olduğuna dikkat çekmişlerdir. Bu kategori altında yer alan öğretmen metaforları Tablo 6'da verilmiştir:

Tablo 6. "Tasarım" Kategorisine Ait Öğretmen Metaforları

\begin{tabular}{cccccc}
\hline & \multicolumn{2}{c}{ Tasarım } & & Metafor & f \\
\hline Metafor & $\mathbf{f}$ & Metafor & $\mathbf{f}$ & Ayna & 1 \\
Tasarım & 2 & Nanoteknoloji & 1 & Çiçek & 1 \\
Yeni Ürün & 2 & Sanat & 1 & Yaşamın kolaylaşması & 1 \\
Yap-boz & 1 & Üretim & 1 & & \\
Hayal gücü & 1 & & & & \\
\hline
\end{tabular}

“Tasarım” kategorisine ait örnek öğretmen metaforları aşağıda verilmiştir:

Proje çiçek gibidir. Çünkü yeni çiçekler meydana getirirler (K36),

Proje yeni ürün gibidir. Çünkü kişinin bilgi ve tecrübesinin sonucu ortaya çıkan üründür (K38),

Proje sanat gibidir. Çünkü kişi kendi karakterini yansıtarak özgün ürünler ortaya koyar (K43),

Proje ayna gibidir. Çünkü ne yaparsan yap kendinden bir şey ve ürün ortaya koyarsın (K46),

Proje üretim gibidir. Çünkü var olan sorunlara çözüm üretmek ve yeni şeyler ortaya koymak projeyle olur (K44).

\section{Süreç yönünden proje çalışması}

Süreç kategorisi altında öğretmenlerin 10 metafor ürettikleri tespit edilmiştir. Metaforlar incelendiğinde, öğretmenlerin proje çalışmalarının belli aşamaları olan ve belli bir süreci içeren çalışmalar olduğunu ifade ettikleri görülmektedir. Bu kategori altında yer alan öğretmen metaforları Tablo 7'de verilmiştir:

Tablo 7. "Süreç" Kategorisine Ait Öğretmen Metaforları

\begin{tabular}{clcccc}
\hline & \multicolumn{5}{c}{ Süreç } \\
\hline Metafor & f & Metafor & f & Metafor & f \\
\hline Araştırma ödevi & 1 & Yolculuk & 1 & Gelecek & 1 \\
Plan & 1 & Hayat & 1 & Sonsuz olasılıklar & 1 \\
Çiçek & 1 & Yap/öğren & 1 & Üretim & 1 \\
Öğrenme & 1 & & & & \\
\hline
\end{tabular}

"Süreç" kategorisine ait örnek öğretmen metaforları aşağıda verilmiştir:

Proje plan gibidir. Çünkü belli adımların birleşmesinden meydana gelen belli bir süreçtir (K48), 
Proje yolculuk gibidir. Çünkü yola çıktı̆̆ınızda belli sürede görerek, yaparak yaşayarak sonuca ulaşırsınız (K50),

Proje hayat gibidir. Çünkü karşılaşılan problemler belli aşamalardan geçerek çözülür (K51),

Proje gelecek gibidir. Çünkü geleceğin planlanması gibi proje de plan ve aşama içerir (K53).

\section{Mutluluk kaynağg yönünden proje çalışması}

Mutluluk kaynağı kategorisi altında öğretmenlerin 6 metafor ürettikleri tespit edilmiştir. Metaforlar incelendiğinde öğretmenler, proje çalışmalarının insanlara mutluluk getirdiği yönünde fikirlerini ifade etmişlerdir. Bu kategori altında yer alan öğretmen metaforları Tablo 8'de verilmiştir:

Tablo 8. “Mutluluk Kaynağı” Kategorisine Ait Öğretmen Metaforları

\begin{tabular}{cccccc}
\hline & \multicolumn{5}{c}{ Mutluluk Kaynağı } \\
\hline Metafor & $\mathbf{f}$ & Metafor & $\mathbf{f}$ & Metafor & f \\
\hline Yemek & 1 & Düş & 1 & Lezzetli yemek & 1 \\
Matematik problemi & 1 & İlim dünyasına adım & 1 & Tekerleğin icadı & 1 \\
\hline
\end{tabular}

"Mutluluk kaynağı" kategorisine ait örnek öğretmen metaforları aşağıda verilmiştir:

Proje yemek gibidir. Çünkü hazırlarken bile her anında sonuna ulaşmak için mutluluk yaşarız (K56),

Proje düş gibidir. Çünkü hayal ile proje yaparken yaşarsınız mutluluğu (K58),

Proje lezzetli yemek gibidir. Çünkü tadına varınca vazgeçemezsin (K60),

Proje tekerleğin icadı gibidir. Çünkü projeler ilerledikçe ve geliştikçe hayatına renk katar (K61).

\section{GereksizJfaydasız yönünden proje çalışması}

Gereksiz/Faydasız kategorisi altında öğretmenlerin 6 metafor ürettikleri tespit edilmiştir. Metaforlar incelendiğinde öğretmenler, proje çalışmalarının öğrenciler açısından sadece not amaçlı olduğu, belli bir getirisi olmadığı yönünde görüşlerini ifade etmişlerdir. Bu kategori altında yer alan öğretmen metaforları Tablo 9'da verilmiştir:

Tablo 9. “Gereksiz/Faydasız” Kategorisine Ait Öğretmen Metaforları

\begin{tabular}{cccccc}
\hline & \multicolumn{5}{c}{ Gereksiz/Faydasız } \\
\hline Metafor & f & Metafor & f & Metafor & f \\
\hline Angarya & 1 & Yemek & 1 & Yillı̈ ödev & 1 \\
Yazılı & 1 & Seyirci Jokeri & 1 & Sabun köpügü & 1 \\
\hline
\end{tabular}

“Gereksiz/Faydasız” kategorisine ait örnek öğretmen metaforları aşağıda verilmiştir:

Proje ylllı ödev gibidir. Çünkü bizim dönemde de her ögrrenci yıllık ödev almak zorundaydl. Yani pek bir faydasi yok (K62),

Proje sabun köpüğü gibidir. Çünkü önce parlatılır ama sonuca ulaşamaz (K63),

Proje seyirci jokeri gibidir. Çünkü ders notu düşük olan bir öğrenci proje sayesinde dersten geçebilir. Hiçbir faydast yok (K64),

Proje yemek gibidir. Çünkü sadece öğrencinin notunun yükselmesi için gerekli (K65). 


\section{Proje Çalışmalarının Yararları}

Öğretmenlerin proje kavramına ilişkin algılarını metaforlar yoluyla ortaya koyduktan sonra, öğretmenlere "Okulunuzda rehberliğini yaptığınız proje çalışmalarının (ödevlerinin) yararları hakkında düşünceniz nelerdir?" sorusu yöneltilmiştir. Fen bilimleri öğretmenleri tarafından verilen cevaplara içerik analizi yapılmış ve proje çalışmalarının yararları kategorisi altında elde edilen kodlar Tablo 10'da verilmiştir:

Tablo 10. Proje Çalışmalarının Yararları

\begin{tabular}{|c|c|c|c|}
\hline Kodlar & $\mathbf{f}$ & $\%$ & Örnek cümle \\
\hline $\begin{array}{l}\text { Merak ve araştırma } \\
\text { duygusunu geliștirir }\end{array}$ & 16 & 19,51 & $\begin{array}{l}\text { Öğrenci bir probleme çözüm bulmanın mutluluğunu } \\
\text { yașar (K7) }\end{array}$ \\
\hline $\begin{array}{l}\text { Öğrencinin özgün fikirler } \\
\text { üretmesini destekler }\end{array}$ & 11 & 13,41 & $\begin{array}{l}\text { Öğrenciye yaratıcı düşünceye ve özgün fikirler } \\
\text { sunmasına firsat verir (K54) }\end{array}$ \\
\hline $\begin{array}{l}\text { Kalıcı öğrenmeye yardımcı } \\
\text { olur }\end{array}$ & 10 & 12,19 & $\begin{array}{l}\text { Fen dersinin soyut konularını somutlaştırma etkisiyle } \\
\text { anlamayı ve kalıcı öğrenmeyi sağlar (K20) }\end{array}$ \\
\hline $\begin{array}{l}\text { Öğrenciyi öğrenme sürecine } \\
\text { dahil eder. }\end{array}$ & 8 & 9,75 & $\begin{array}{l}\text { Öğrencilerin daha aktif olmalarını proje çalışmalarında } \\
\text { aktif görev almalarını destekler (K19) }\end{array}$ \\
\hline Mutluluğu arttırır & 7 & 8,53 & $\begin{array}{l}\text { Farklı çalışmalar yapılarak keyifli ve eğlenceli } \\
\text { öğrenmeye yardımcı olur (K18) }\end{array}$ \\
\hline $\begin{array}{l}\text { Farklı düşünme becerisi } \\
\text { kazandırır }\end{array}$ & 6 & 7,31 & $\begin{array}{l}\text { Öğrencilere yaratıcı düşünme, bilimsel düşünme gibi } \\
\text { farklı düşünme becerisi kazandırır (K54) }\end{array}$ \\
\hline $\begin{array}{l}\text { Öğretmenleri araştırmaya } \\
\text { teşvik eder }\end{array}$ & 4 & 4,87 & $\begin{array}{l}\text { Öğretmenlere de faydası olan proje çalışmaları } \\
\text { araştırma duygusunu geliştirir (K1) }\end{array}$ \\
\hline $\begin{array}{l}\text { Hayal dünyalarını } \\
\text { zenginleştiriyor }\end{array}$ & 3 & 3,65 & $\begin{array}{l}\text { Öğrenciler proje hazırlarken farklı bir boyuta geçiyor } \\
\text { ve hayal dünyalarını genişletmek zorunda kalıyorlar } \\
\text { (K57) }\end{array}$ \\
\hline Özgüveni artırır & 3 & 3,65 & $\begin{array}{l}\text { Projeler öğrencinin yapabileceğini, başarabileceğine } \\
\text { olan özgüvenini artırır (K10) }\end{array}$ \\
\hline $\begin{array}{l}\text { Bir faydası } \\
\text { düşünmüyorum }\end{array}$ & 14 & 17,72 & $\begin{array}{l}\text { Proje çalışmalarında ciddi bir araştırmaya } \\
\text { yönlendirecek bir durum söz konusu değildir ve } \\
\text { ciddiye alınmadığından tatmin edici olmamaktadır } \\
\text { (K63) }\end{array}$ \\
\hline
\end{tabular}

Tablo 10 incelendiğinde; öğretmenlerin proje çalışmalarının yararları hakkında merak ve araştırma duygusunu arttırdığına yönelik görüşlerinin fazla olduğu görülmektedir $(\% 19,51)$. $\mathrm{Bu}$ kapsamda örneğin K59 "Proje çalışmaları ögrencilerde merak uyandırmaktadır. Bir proje konusu, diğerinin kapısını araladığından ögrenciyi yeni yeni şeyler öğrenmeye ve araştırmaya sevk etmektedir." şeklinde görüşünü ifade ederken; K60 “ Proje çalışmaları çocuklarl derse ve okula karşı daha istekli killyor. Çocuklarda merak duygusu geliştiriyor.” şeklinde görüşünü belirtmiştir. Aynı şekilde K52 "Proje çocuklarda hem merak hem istek uyandırır ve zevkli bir aktivite sonrası araştırmaya yönlendirir." şeklinde görüşünü ifade ederken; K38 "Proje çalışmaları ögrenciyi meraka ve araştırmaya iter.” şeklinde görüşünü belirtmiştir.

Öğretmenler ikinci olarak proje çalışmalarının öğrencileri özgün fikirler üretme yönünden desteklediğini ifade etmişlerdir $(\% 13,41)$. Bu kapsamda K17 görüşünü "Proje çalışmaları her derste verimli bir çalışma olup öğrencilerin farklı ve özgün fikir ve ürünler oluşturmasına firsat verir." şeklinde görüşünü ifade ederken; K56 "Dar kaliplardan uzaklaşarak öğrenciyle bir oluşumun içinde olmak, ürün ortaya koymak öğrenme ve farklı fikirler sunmada onlara ciddi katkl sağlar." şeklinde görüşünü belirtmiştir.

Fen bilimleri öğretmenleri proje çalışmalarının kalıcı öğrenmeye yardımcı olduğunu da ifade etmişlerdir $(\% 12,19)$. Proje çalışmaları sistematik bir şekilde yürütülürse öğrenmenin daha 
sağlıklı bir şekilde olacağı öğretmenler tarafindan belirtilmiştir. Bu kapsamda K47 "Öğrenci konu hakkında daha özel bir araştırma yaptı̆̆ için konunun detaylarını daha iyi ögrenebilir." şeklinde görüşünü ifade ederken, K49 "Çocuklar yaparak yaşayarak öğrenme imkanı buluyorlar, süreç içerisinde kalıcı izli ögrenmeler gerçekleşiyor. Öğrenme alanı açısından kazanımlar süreç içerisinde pekiştirilerek veriliyor." şeklinde görüşünü belirtmiştir. Öğretmenlerin proje çalışmalarının diğer yararları hakkında; öğrenciyi öğrenme sürecine dahil ettiğini, mutlu olmalarını sağladığını, farklı düşünme becerileri kazandırdığı, öğretmenleri çalışmaya teşvik ettiği, öğrencilerin hayal dünyalarını zenginleştirip özgüvenlerini arttırdığını da ifade etmişlerdir. Bununla birlikte katılımcıların kayda değer bir kısmı $(\% 17,72)$ proje çalışmalarının öğrencilere ve öğretmenlere bir yarar sağlamadığını ifade etmişlerdir. Bu kapsamda K48 "Üretici ve yaratıcı bağlamda çok faydası olduğunu düşünmüyorum. Sadece not bağlamında ögrencilere bir katkısı var." şeklinde görüşünü ifade ederken K43 “Öğrenciler emek vermeden hazır projelerden çok faydalaniyorlar. O yüzden istenilen ögrenme düzeyine ulaşılamıyor." şeklinde görüşünü belirtmiştir. Proje çalışmalarının yararlı olmadığını ifade eden bazı örnek öğretmen görüşleri şu şekildedir:

Proje çalışmalarının yararlı olduğunu düşünmüyorum. Çünkü verilen projeler internet üzerinden indirilip yapıllyor (K66),

Yararlı olduğunu düşünmüyorum. Ödev yapmaya ve sorumluluk sahibi olmayan ögrenciye not otoritesiyle ödev yaptırmanın gereksiz olduğunu düşünüyorum (K67),

Öğrenciler projeyi daha çok notlarını yükseltmek için kullandıkları için projenin çok amacına ulaştığını düşünmüyorum (K62),

Öğrenciler tarafindan çok yaratıcı denebilir proje konuları gelmemekte. Dolayısıyla ögrenciyi ciddi bir araştırmaya yönlendirecek bir durum söz konusu olmamaktadır (K63),

Okullardaki projelerin eğitim sistemimizin sınava yönelik ve başka faaliyetlere kapalı olması sebebiyetiyle projeler amacına ulaşmıyor (K9).

\section{Proje Çalışmalarında Karşılaşılan Problemler}

Öğretmenlere "Proje çalışmalarında nasıl problemlerle karşılaşıyorsunuz?" sorusu yöneltilmiş olup verdikleri cevaplara içerik analizi yapılarak kod ve kategoriler belirlenmiştir. Bu kapsamda elde edilen veriler Tablo 11'de verilmiştir:

Tablo 11 incelendiğinde; katılımcıların en çok proje çalışmalarında veri toplama aracına ulaşma noktasında sorun yaşadıklarını ifade etmişlerdir $(\% 24,39)$. Buna yönelik olarak örneğin K16 "Proje çalışmalarında teknolojik araç gereçlerin temini konusunda yaşanılan sorunlar var." şeklinde görüşünü belirtirken, K19 "Konuya uygun araç gereçleri bulmakta sorun yaşanıyor." şeklinde görüşünü ifade etmiştir. Yaşanan bu probleme yönelik örnek katılımc1 cümleleri şu şekildedir:

Araç gereç eksikliği sorunu yaşlyorum (K8),

Proje çalı̧̧malarında bazen malzeme bulmakta güçlük çekilebiliyor (K4),

Karşılaş̧ı̆̆ım en büyük problem projeye uygun bir atölyenin bulunmayışı, araç gereçlerin yeterli düzeyde olmaması (K31),

Proje çalışmalarında malzeme sıkıntısı yaşanmaktadır (K30), 
Malzeme konusunda imkanımız kısitlı (K29).

Tablo 11. Proje Çalışmalarında Karşılaşılan Problemler

\begin{tabular}{|c|c|c|c|}
\hline Kodlar & f & $\%$ & Örnek cümle \\
\hline $\begin{array}{l}\text { Veri toplama aracına ve } \\
\text { malzemeye ulaşmada sorun } \\
\text { yaşıyoruz }\end{array}$ & 20 & 24,39 & $\begin{array}{l}\text { Proje uygulamaları yapmak için ortam ve malzeme } \\
\text { yetersizliği yaşanıyor (K60) }\end{array}$ \\
\hline Süre sorunu yaşanıyor & 17 & 20,73 & $\begin{array}{l}\text { Proje çalışmalarında süre sorunu yaşayan çocuklar } \\
\text { zamanında proje teslimi gerçekleşmiyor (K64) }\end{array}$ \\
\hline $\begin{array}{l}\text { Proje konusunda öğrenciler } \\
\text { isteksiz ve özensiz oluyor }\end{array}$ & 14 & 17,07 & $\begin{array}{l}\text { Proje çalışmalarında isteksizlik ve düzensizlik büyük } \\
\text { problemdir (K43) }\end{array}$ \\
\hline $\begin{array}{l}\text { Not yükseltmek amaçlı } \\
\text { projeler yapıllyor }\end{array}$ & 11 & 13,41 & $\begin{array}{l}\text { Proje çalışmaları öğrencilerin not almak için yaptıkları } \\
\text { ödev olarak görülüyor (K67) }\end{array}$ \\
\hline $\begin{array}{l}\text { Öğrenci özgün proje konusu } \\
\text { belirleyemiyor }\end{array}$ & 10 & 12,19 & $\begin{array}{l}\text { er projeleri belirlerken kisa yoldan internetten } \\
\text { iir (K10) }\end{array}$ \\
\hline $\begin{array}{l}\text { Rapor aşamasında sorun } \\
\text { yaşanıyor }\end{array}$ & 3 & 3,65 & $\begin{array}{l}\text { En büyük problem düşündüklerimizi ve yaptıklarımızı } \\
\text { kağıda dökemememiz (K15) }\end{array}$ \\
\hline $\begin{array}{l}\text { Grup projelerinde sorunlar } \\
\text { yaşanıyor }\end{array}$ & 3 & 3,65 & $\begin{array}{l}\text { Proje çalışmalarında ekip olunca anlaşma sorunu } \\
\text { yaşanıyor (K24) }\end{array}$ \\
\hline $\begin{array}{l}\text { Veliler projelere destek } \\
\text { olmuyor }\end{array}$ & 2 & 2,43 & $\begin{array}{l}\text { Velilerin maddi yetersizliği ve ilgisizliği engel } \\
\text { oluşturabiliyor (K49) }\end{array}$ \\
\hline $\begin{array}{l}\text { Okul dersleri yoğun } \\
\text { olduğundan proje çalışmaları } \\
\text { verimli olmuyor }\end{array}$ & 2 & 2,43 & $\begin{array}{l}\text { Okullarda ders zamanının fazla olması ve sınavların } \\
\text { ağır olması öğrencileri projeden uzaklaştırıyor (K36) }\end{array}$ \\
\hline
\end{tabular}

Katılımcılar proje çalışmalarında diğer bir sorun olarak süre sorununa dikkat çekmişlerdir $(\% 20,73)$. Bu kapsamda verilen cevaplar incelendiğinde katılımcıların; öğrencilerin süreyi doğru kullanmada, istenilen tarihte teslim etmede ve süreci yönetmede sorun yaşadıklarını dile getirdikleri görülmüştür. Örneğin buna yönelik görüşünü K37 "Okulda yapılan projelerde zaman sorunu yaşlyoruz.” şeklinde görüşünü belirtirken K3, “Öğrencilerin ödevleri zamanında teslim etmemeleri en önemli problem." ş̧eklinde görüşünü belirtmiştir. Bununla birlikte bazı katılımcılar öğrencilerin proje konusunda istekli olmadıklarını ve çalışmalarda titiz davranmadıklarını ifade etmişlerdir (17,07). Bu duruma yönelik K23 "Verilen proje ödevlerine ögrencilerin genelde çok çaba harcamadılarını düşünüyorum.” ş̧eklinde görüşünü belirtirken, K27 “Yaşanan problem öğrencilerin önemsiz davranmasıdır." şeklinde görüşünü ifade etmiştir.

Katılımcıların önemli bir kısmı $(\% 13,41)$ yapılan projelerin not yükseltme amaçlı yapıldığını ifade etmişlerdir. Bu kapsamda örneğin K44 "Proje çalışmaları amacına uygun yürümüyor. Öğrenciler proje ödevini not yükseltme olarak görüyor." şeklinde görüşünü ifade ederken, K11 “Öğrencilerin not yükseltme nedeni ile proje alması büyük bir problem." şeklinde görüşünü ifade etmiştir. Bununla birlikte katılımcılar öğrencilerin özgün proje üretemediklerini de ifade etmişlerdir $(\% 12,19)$. Bu duruma yönelik örneğin K1 “ Öğrencilerin proje çalışmalarında kendinden bir şeyler katma yönleri oldukça zayıftır. Özgün eserler veya çalışmalar yoktur." şeklinde görüşünü belirtirken, K24 "Öğrencilerin farklı düşünceler ortaya koyamamast ve internette var olan projeleri taklit etmeleri." şeklinde problemi ortaya koymuştur.

$\mathrm{Bu}$ problemlere ek olarak fen bilimleri öğretmenleri; rapor yazmada ve grup projelerinde sorun yaşandığını $(\% 3,65)$, velilerin proje çalışmalarına destek olmadıklarını $(\% 2,43)$, okul dersleri yoğun olduğundan proje çalışmalarında istenilen verimin alınamadığını 
$(\% 2,43)$ da ifade emişlerdir. Yaşanan bu problemlere yönelik K14, velilerin destek olmadığını “ Bazı veliler katılım sağlamak istemeyebiliyor." şeklinde ifade ederken, K35 "Ekiple yapılan proje çalışmalarında sorunlar oluyor." şeklinde görüşünü ifade etmiştir.

\section{Çözüm Önerileri}

Katılımcılara "Proje çalışmalarında karşılaştığınız problemlere yönelik çözüm öneriniz melerdir?" sorusu yöneltilmiştir. Elde edilen verilere içerik analizi yapılmış olup bu doğrultuda kategori ve kodlar oluşturulmuştur. Katılımcı görüşleri doğrultusunda çözüm önerileri teması altında belirlenen kategori ve kodlar Tablo 12'de verilmiştir:

Tablo 12. Çözüm Önerileri

\begin{tabular}{|c|c|c|c|}
\hline Kodlar & $\mathbf{f}$ & $\%$ & Örnek cümle \\
\hline $\begin{array}{l}\text { Öğrencilerin proje çalışmalarını } \\
\text { yönelik rehberlik edilmeli }\end{array}$ & 36 & 43,90 & $\begin{array}{l}\text { Öğrencilere sürekli olarak itici güç olarak } \\
\text { rehberlik edilmeli (K51) }\end{array}$ \\
\hline $\begin{array}{l}\text { Okullarda proje atölyeleri ve } \\
\text { sinıfları kurulmalı }\end{array}$ & 14 & 17,07 & $\begin{array}{l}\text { Proje atölyeleri kurulmalı ve her atölye belli } \\
\text { dersin alanına göre düzenlenmeli (K } 31)\end{array}$ \\
\hline Okulun teknik imkanları arttırılmalı & 12 & 14,63 & $\begin{array}{l}\text { Okulların materyal boyutunda daha fazla } \\
\text { donanımlarının olması (K19) }\end{array}$ \\
\hline Projeler için bütçe ayrılmalı & 7 & 8,53 & Okullara projeler ile ilgili bütçe ayrılsın (K54) \\
\hline $\begin{array}{l}\text { Öğretmenlerin ve idarecilerin proje } \\
\text { çalışmalarına yönelik desteklenmesi } \\
\text { gerekir }\end{array}$ & 5 & 6,09 & $\begin{array}{l}\text { Proje çalışmaları için öğretmenlerin, okul } \\
\text { müdürlerinin desteklenmesi, pekiştirilmesi } \\
\text { gerekir (K49) }\end{array}$ \\
\hline Ders saatleri azaltılmalı & 3 & 3,65 & En başta ders saatlerimiz azaltılmalı (K62) \\
\hline $\begin{array}{l}\text { Proje çalışmaları küçük yaşlarda } \\
\text { başlamalı }\end{array}$ & 3 & 3,65 & Öğrenci projesine ilk okulda başlamalı (K39) \\
\hline Diğer kurumlarla işbirliği yapılmalı & 2 & 2,43 & $\begin{array}{l}\text { Üniversiteler ve diğer meslek liseleri proje } \\
\text { çalışmaları için gerekli yardımı yapmalı (K63) }\end{array}$ \\
\hline
\end{tabular}

Tablo 12 incelendiğinde; katılımcıların önemli bir kısmı $(\% 43,90)$ öğrencilere proje çalışmalarını sevdirmek ve proje çalışmalarında istenilen verimi elde edebilmek için rehberlik çalışmalarına önem verilmesi gerektiğini vurgulamışlardır. Bu kapsamda örneğin K1 "Öğrenciye rehberlik açısından ve fikir vermek açısından yardımcı olunabilir." şeklinde görüşünü belirtirken, K17 “Proje süresi boyunca iletişim halinde olmaya çalışıyorum.” şeklinde görüşünü belirtmiştir. Bununla birlikte katılımcılar proje atölyeleri ve sinıfları kurulması noktasında da yoğun bir şekilde görüş bildirmişlerdir (\%17,07). Buna yönelik görüşünü örneğin K18 "Bu çalı̧̧maların etkili bir şekilde yürütülebilmesi için bir sınıf ya da laboratuara ihtiyaç vardır."şeklinde ifade ederken, K60 "Okul laboratuar ve sınıflarının proje çalışmalarını yapabilmek için donanımlı hale getirilmesi ve buna yönelik atölyelerin açılması gerekmekte." şeklinde görüşünü belirtmiştir.

Bazı katılımcılar $(\% 14,63)$, okulların teknik imkânlarının iyileştirilmesi ve proje çalışmaları için gerekli olabilecek malzemelerin temin edilmesini önermişlerdir. Bu duruma yönelik görüşünü K6 "Altyapı iyileştirilmeli, projelerde malzeme sorunu yaşanmamall." şeklinde ifade ederken, K22 "Okullarda proje yapılabilmesi için gerekli alanların oluşturulması, gerekli araç gereçlerin temin edilmesi gerekir." şeklinde ifade etmiştir. Ayrıca bazı katılımcılar $(\% 8,53)$, proje çalışmalarının sağlıklı yürütülebilmesi için bütçe ayrılması gerektiğini ifade etmişlerdir. Bu duruma yönelik örneğin K50 "Maddi destekle problemler çözüme kavuşur." şeklinde görüşünü belirtirken, K82 "Okul binalarının daha donanımlı hale gelebilmesi için bütçenin ayrılması gerekir.” şeklinde görüşünü belirtmiş̧ir. Bununla birlikte bazı katılımcılar; öğretmenlerin ve idarecilerin proje çalışmaları kapsamında 
desteklenmesi $(\% 6,09)$, proje çalışmalarına küçük yaşlarda başlanması $(\% 3,65)$, ders saatinin azaltılması $(\% 3,65)$ ve diğer kurumlarla işbirliği yapılması $(\% 2,43)$ noktasında da görüş belirtmişlerdir.

\section{Tartışma ve Sonuç}

$\mathrm{Bu}$ çalışmada, fen bilimleri öğretmenlerinin proje algılarının ve rehberlik ettikleri proje çalışmalarına yönelik görüşlerinin incelenmesi amaçlanmıştır. Bu kapsamda proje çalışmalarına rehberlik eden 82 fen bilimleri öğretmeni ile çalışma yürütülmüştür. Çalışma kapsamında ilk olarak fen bilimleri öğretmenlerinin proje kavramına ilişkin metaforik algıları incelemiştir.

Fen bilimleri öğretmenlerin proje kavramına ilişkin 68 tane metafor ürettikleri, 14 öğretmenin ise metafor üretmede zorluk çektikleri sonucuna ulaşılmıştır (Tablo 2). Buradan hareketle görev yapmakta olan fen bilimleri ögretmenlerinin proje kavramına ilişkin algılarının yeterli düzeyde olmadığ 1 yorumuna varılabilir. Deneyimli öğretmenlerin rehberliğinde yürütülen proje çalışmalarının daha verimli olduğu vurgulanmaktadır (Habók ve Nagy, 2016). Bununla birlikte öğretmenlerin proje çalışmalarına yönelik olumlu algıya sahip olmaları, öğrencilerin verimli ve özgün proje üretmelerine ve yeni eğitim sistemine uyum sağlamalarına yardımcı olacağı düşünülmektedir. Çünkü üretim ve inovasyon odaklı deneyimli iş gücü yetiştirmeye, üretimi hızlandıracak sürdürülebilir öğrenme ortamları oluşturarak öğrenciyi merkeze alan yeni eğitim sisteminde, proje çalışmalarına daha fazla önem verilmektedir (Katharina ve Dominic, 2015). Dolayısıyla fen bilimleri öğretmenlerinin proje algılarının yetersiz olması, üzerinde durulması gereken bir problem olarak görülmektedir. Öğretmenlerin proje kavramına yönelik yeterli algı düzeyine sahip olmamalarına lisans eğitimlerinde proje çalışmalarına yönelik teorik ve uygulamalı eğitimleri almaması sebep olarak gösterilebilir. Çünkü başarılı yürütülen proje çalışmalarında öğretmenlerin aldıkları eğitimler önemlidir (Wu ve Meng 2010). Buradan hareketle lisans eğitimleri süresince öğretmen adaylarına proje çalışmalarına yönelik teorik ve uygulamalı eğitimlerin verilmesi gerektiği yorumu yapılabilir.

Öğretmenlerin proje kavramına ilişkin metaforları incelendiğinde en çok “Öğrenmeye yardımcl" kategorisi altında metafor ürettikleri tespit edilmiş olup gerekçe kısmında öğretmenler, proje çalışmalarının anlamlı öğrenmeyi sağlayarak kalıcı öğrenmeye yardımcı olduğunu belirtmişlerdir (Tablo 3). Proje çalışmalarında öğrenciler, gerçek dünya sorunlarına aktif öğrenme, yansıtma ve paylaşma süreçleri ile birlikte çözüm ararlar ve bu şekilde öğrenmelerinin kalıcı olmasını sağlarlar (English ve Kitsantas, 2013). Bu bakımdan proje çalışmalarına yönelik öğretmenlerin algıları dikkate değer bir sonuçtur. Aynı şekilde öğretmenler proje çalışmalarında istenilen verimin alınması için çaba gösterilmesine yönelik belli sayıda metafor ürettikleri de tespit edilmiştir (Tablo 3). Buradan hareketle öğretmenlerin proje çalışmalarını emek isteyen bir süreç olarak gördükleri yorumuna varılabilir. Ayrıca bu sonuç, proje çalışmalarının doğası gereği değerli görülmektedir. Çünkü proje çalışmaları; planlama, araştırma, seçme, sunma gibi uzun bir süreç içermekte (Holm, 2011) ve proje çalışmalarında ögrencilerin belli bir emek harcaması gerekmektedir. Bununla birlikte bazı katılımcılar $(\% 17,64)$, proje çalışmalarında ürün ve tasarım boyutuna yönelik metafor üretmişlerdir (Tablo 3). Elde edilen sonuç bazı çalışmalarla benzerlik göstermektedir (Coşkun, 2004; Kılıç ve Özel, 2015; Önen, Mertoğlu, Saka ve Gürdal, 2010). Örneğin Kılıç ve Özel (2015) yaptıkları çalışmada, öğretmen ve velilerin projeye kavramına yönelik görüşlerinin yeni bir ürün tasarlamak veya üretmek olduğunu ifade etmişlerdir. Bir ürün ve sunumla sonuçlanan 
proje çalışmalarında (Barron ve Darling-Hammond, 2008) öğretmenlerin ürün ve tasarıma yönelik algıları önemli görülmektedir. Çünkü proje çalışmalarının en önemli özelliği belli bir süre içinde bir ürün ortaya koymaktır (Lenz, Wells, ve Kingston, 2015).

Katılımcılara proje çalışmalarının yararlarına yönelik görüşleri sorulduğunda birçoğu, proje çalışmalarının öğrencilerde merak ve araştırma duygusunu geliştirerek özgün ürünler üretmesine firsat verdiğine yönelik görüşler öne sürmüşlerdir (Tablo 10). Alan yazında birçok öğrenme alanında kullanılabilecek olan proje çalışmalarının (Chen ve Yang, 2019); akademik başarıyı (Panasan ve Nuangchalerm, 2010), öğrencilerin derse olan merak ve ilgisini (Bender, 2012) ve yaratıcılığını arttırarak özgün ürünler ortaya koymasına firsat verdiği belirtilmektedir (Duke, 2016). Dolayısıyla fen bilimleri öğretmenlerinin proje çalışmalarının öğrencilerin belirtilen özellikleri geliştirdiklerini ifade etmeleri önemli görülmektedir. Bununla birlikte katılımcıların önemli bir kısmı projelerin öğrenciyi öğrenme sürecine dâhil ederek kalıcı öğrenmeye yardımcı olduğunu da belirtmişlerdir (Tablo 10). Bu sonuçla birlikte öğretmenlerin proje çalışmalarının yararlarına yönelik birçok farklı görüşe sahip oldukları yorumuna varılabilir. Ayrıca bu sonuç proje çalışmalarının doğası gereği beklenen bir durumdur. Çünkü bir proje çalışmasının, öğrenciyi öğrenme ortamlarına katma, öğrencinin akranları ile birlikte tartışmalar ve sunum yapmalarına firsat verme ve anlamlı öğrenmesine yardımc1 olma gibi birçok yararı olduğu ifade edilmektedir (Johnson, Renzulli, Bunch ve Paino, 2013).

Fen bilimleri öğretmenlerine proje çalışmalarında karşılaştıkları problemler sorulduğunda katılımcıların önemli bir kısmı; proje çalışmaları esnasında veri toplama aracına ulaşmada, malzemelerin temininde ve öğrencilerin süreyi doğru kullanmasında sorun yaşadıklarını ifade etmiş̧lerdir (Tablo 11). Buradan hareketle öğretmenlerin proje çalışmaları süresince farklı birçok problemle baş etmek zorunda kaldıkları yorumu yapılabilir. Ayrıca elde edilen bu sonuç bazı çalışmalarla benzerlik göstermektedir (Boss 2012; Weber, 2019). Örneğin Boss (2012) yaptığı çalışmada, öğretmenlerin proje çalışmalarının çok zaman aldığına yönelik görüşlere sahip olduğunu ifade etmiştir. Aynı zamanda pahalı olabilen proje çalışmalarında malzeme eksikliğinin de yaşanması çalışmadan istenilen sonucun alınmasını engelleyebilir. Bu bakımdan öğretmen görüşlerinin dikkate alınması gerekmektedir. Bununla birlikte öğrencilerin proje çalışmalarında özensiz ve isteksiz oldukları ve sadece notlarını yükseltmek için proje çalışmaları yaptıkları sonucuna da ulaşılmıştır (Tablo 11). Elde edilen bu sonuç Arı (2010) tarafindan yapılan çalışma ile benzerlik göstermektedir. Arı (2010) yaptığı çalışmada, öğretmenlerin büyük bir çoğunluğu öğrencilerin proje çalışmalarına ilgi ve önem göstermediklerini ifade etmiştir. Öğrencilerin proje çalışmalarını sadece not amaçlı olarak görmeleri, yürütülen proje çalışmalarının amacına hizmet etmemesine sebep olmaktadır. Buna yönelik gerekli önlemlerin alınması önemlidir (Esen ve Güneş, 2012). Çünkü alternatif ölçme araçlarının amacı sonuçtan ziyade sürece önem vererek öğrencilerin gelişimlerini takip edebilmektir.

Fen bilimleri öğretmenlerinin büyük bir çoğunluğu proje çalışmalarının verimli bir şekilde yürütülebilmesi için öğrencilere proje sürecinde sürekli rehberlik edilmesi ve okullarda proje atölyeleri ile sınıflarının kurulması gerektiğini önermiştir (Tablo 12). Öğretmenlerin proje çalışmalarının tüm sürecinde öğrencilere rehberlik etmesi (Saracaloğlu ve Çelik, 2018) öğrencilerin projelere karşı istekli olmasını ve projeyi sahiplenip verimli çalışmalar yapmasını sağlayacağı düşünülmektedir. Aynı şekilde proje sınıflarının kurulması, proje çalışmalarına 
gerekli önemin verilmesi noktasında değerlidir. Bunun için de katılımcıların belirttiği üzere okulun teknik imkânlarının iyileştirilmesi ve proje çalışmaları için belli bir bütçenin ayrılması gerektiği yorumuna varılabilir.

\section{Öneriler}

Fen bilimleri öğretmenlerinin 21. yüzyıl becerilerinin öğrencilere aktarılmasında etkili yollardan birisi olan proje çalışmalarına ilişkin algılarının iyileştirilmesi ve olumsuz algılarının önüne geçmek için lisans eğitimleri boyunca proje çalışmalarına ağırlık verilmesi önerilmektedir.

Fen bilimleri öğretmenlerinin sistematik bir şekilde proje çalışmalarına rehberlik edebilmeleri için okul imkânlarının iyileştirilmesi, bu kapsamda teknolojik laboratuar ve proje atölyelerinin kurulması önerilmektedir.

Öğretmenlerin mezun olduktan sonra proje çalışmaları gibi alternatif ölçme ve değerlendirme faaliyetleri açısından eksikliklerinin tespit edilmesi ve gerekli hizmet içi eğitimlerin verilmesi önerilmektedir.

$\mathrm{Bu}$ çalışma 82 fen bilimleri öğretmeni ile sınırlı olup çalışmanın kapsamı genişletilerek öğretmenlerin proje algısı ve proje çalışmalarına ilişkin görüşleri daha büyük bir örneklem üzerinde incelenebilir. 


\section{Kaynakça}

Akbaş, Y. ve Gençtürk, E. (2013). Coğrafya öğretmenlerinin alternatif ölçme-değerlendirme teknikleri ile ilgili görüşleri: Kullanma düzeyleri, sorunlar ve sınırlılıklar. Doğu Coğrafya Dergisi, 18(30), 331355 .

Allison, J. M. (2018). Project based learning to promote 21st century skills: an action research study. Dissertations, Theses, and Masters Projects. http://dx.doi.org/10.25774/w4-m5xm-wc95

Arı, A. (2010). Öğretmenlere göre proje ve performans görevlerinin uygulanmasında karşılaşılan sorunlar. Electronic Journal of Social Sciences, 9(34), 32-55.

Atabek-Yiğit, E. ve Balkan-Kıyıcı, F. (2018). Bilişsel stiller ve alternatif ölçme ve değerlendirme araçlarının kullanım yeterliği arasındaki ilişkinin incelenmesi. Scientific Educational Studies, 2(1), 39-55.

Barron, B., \& Darling-Hammond, L. (2008). How can we teach for meaningful learning? In L. DarlingHammond (Ed.). Powerful learning: What we know about teaching for understanding. 11-70. San Francisco, CA: Jossey-Bass.

Bayat, S. ve Şentürk, Ş. (2015). Fizik, kimya, biyoloji ortaöğretim alan öğretmenlerinin alternatif ölçme değerlendirme tekniklerine ilişkin görüşleri. Amasya Üniversitesi Eğitim Fakültesi Dergisi 4(1), 118-135.

Bender, W. N. (2012). Project-based learning: Differentiating instruction for the 21 st century (1st ed.). Thousand Oaks, CA: Corwin.

Boss, S. (2012). The challenges of assessing project-based learning. District Administration, 48(9), 46-52.

Büyüköztürk, Ş., Kılıç-Çakmak, E., Akgün, Ö. E., Karadeniz, Ş. ve Demirel, F. (2011). Bilimsel araşttrma yöntemleri. Ankara: Pegem A.

Carpenter, J. (2008). Metaphors in qualitative research: shedding light or casting shadows?. Research in Nursing \& Health, 31, 274-282.

Chen, C.H., \& Yang, Y.C. (2019). Revisiting the effects of project-based learning on students'academic achievement: A meta-analysis investigating moderators. Educational Research Review, 26, 71-81.

Coşkun, M. (2004). Coğrafya öğretiminde proje yaklaşımı. G.Ü. Kırşehir Eğitim Fakültesi Dergisi, 5(2), 99-107.

Çoruhlu, Ş. T., Ernas, S. ve Çepni, S. (2009). Fen Bilimleri öğretmenlerinin alternatif ölçme değerlendirme tekniklerini kullanmada karşılaştıkları problemler: Trabzon örneği. Yüzüncü Yıl Üniversitesi Ĕ̈itim Fakültesi Dergisi, 6(1), 122-141.

Duke, N. K. (2016). Project-based instruction. American Educator, fall, 4-12.

Egodawatte, G. (2010). A Rubric to self-assess and peer-assess mathematical problem solving tasks of college students. Acta Didactica Napocensia, 3(1), 75-88.

Ekici, G. (2016). Öğretmen adaylarının 'Bilgisayar' kavramına ilişkin metaforik algıları. University of Gaziantep Journal Of Social Sciences, 15(3), 755-781.

English, M. C., \& Kitsantas, A. (2013). Supporting student self-regulated learning in problem and projectbased learning. Interdisciplinary Journal of Problem-Based Learning, 7(2),128-150.

Esen, O. ve Güneş, G. (2012). İlköğretim matematik öğretmenlerinin proje ve performans görevlerine ilişkin görüşleri. Turkish Journal of Computer and Mathematics Education, 3(2), 115-130.

Evmez, S. (2018). Fen bilimleri dersi kapsamında geliştirilen bilim içerikli oyunların ortaokul öğrencileri üzerindeki etkileri. Yüksek Lisans Tezi, Trakya Üniversitesi, Fen bilimleri Enstitüsü, Edirne.

Fallik, O., Eylon, B., S., \& Rosenfeld, S. (2008). Motivating teachers to enact free-choice project-based learning in science and technology (PBLSAT): Effects of a professional development model. Journal of Science Teacher Education, 19, 565-591.

Gömleksiz, M. N., Sinan, A. T. ve Demir, S. (2010). İlköğretim Türkçe dersi proje ve performans görevlerinin gerçekleştirilme sürecine yönelik öğrenci görüşleri (Malatya ili örneği). Turkish Studies International Periodical For the Languages, Literature and History of Turkish or Turkic, 5(3), 1320-1349. 
Habók, A., \& Nagy, J. (2016). In-service teachers' perceptions of project-based learning. Springer Plus, $5(83), 1-14$

Hodges W.J., Lamb P., Brown M.H., \& Foy D.S. (2005), Assessment For All. Science Scope, January, 43-44.

Holm, M. (2011). Project-based instruction: a review of the literature on effectiveness in Prekindergarten through 12th grade classrooms. InSight Rivier Acad J 7(2),1-13.

Johnson, D. R., Renzulli, L., Bunch, J., \& Paino, M. (2013). Everyday observations developing a sociological perspective through a portfolio term project. Teaching Sociology, 41(3), 314-321.

Katharina M., \& Dominic G. (2015). In-factory learning-qualification for the actory of the future. Acta Universitatis Cibiniensis, Technical Series, 159-164.

Keleşoğlu, S. ve Kalaycı, N. (2017). Dördüncü sanayi devriminin eşiğinde yaratıcılık, inovasyon ve eğitim ilişkisi. Yaratıcı Drama Dergisi, 12(1), 69-86.

Kılıç, İ. ve Özel, M. (2015). Proje tabanlı öğrenme yönteminin fen ve teknoloji derslerinde uygulamaları hakkında öğretmen ve veli görüşlerinin incelenmesi. Sakarya University Journal of Education, $5(2), 7-20$.

Ledward, B. C., \& Hirata, D. (2011). An Overview of 21st century skills. honolulu: kamehameha schools research \& evaluation. Retrieved from http://www.ksbe.edu/_assets/spi/pdfs/21st_Century_Skills _Brief.pdf

Lenz, B., Wells, J., \& Kingston, S. (2015). Transforming schools using project-based learning, performance assessment, and common core standards (1st ed.). San Francisco, CA: Jossey-Bass.

MEB (2018). Fen Bilimleri Dersi Öğretim Programı (İlkokul ve Ortaokul 3,4,5,6,7 ve 8. Sinfflar). Ankara.

Miles, M.B., \& Huberman, A. M. (1994). Qualitative data analysis (2. Bask1). Newbury Park, CA: Sage.

Nacaroğlu, O. ve Mutlu, F. (2018). Self-efficacy of the teachers working in the science and art center for project-based learning. İn̈̈nü Üniversitesi Eğitim Fakültesi Dergisi, 19(3), 310-326.

Neukom, J. R. (2000). Alternative assessment: Rubrics-students' self assessment process, master thesis, The Faculty of Pasific Lutheran Universty, U.S.A.

Önen-Öztürk, F. ve Ağlarcı, O. (2019). Öğretmen adaylarının bilim insanlarına ve çalışma yöntemlerine ilişkin görüşleri ve metaforları. Pamukkale Üniversitesi Eğitim Fakültesi Dergisi, 46, 88-107.

Önen, F., Mertoğlu, H., Saka, M. ve Gürdal, A. (2010). Hizmet içi eğitimin öğretmenlerin proje ve proje tabanlı öğrenmeye ilişkin bilgilerine ve proje yapma yeterliliklerine etkisi: Öpyep Örneği. Ahi Evran Üniversitesi Kırşehir Eğitim Fakültesi Dergisi, 1(11), 137-158.

Özbuğutu, E. (2018). Fen bilgisi öğretmen adaylarının evrim kavramına ilişkin metaforik algıları. Academia Eğitim Araştırmaları Dergisi,31(1), 28-43.

Öztuna-Kaplan, A. ve Diker-Coşkun, Y. (2012). Proje tabanlı öğretim uygulamalarında karşılaşılan güçlükler ve çözüm önerilerine yönelik bir eylem araştırması. Mersin Üniversitesi Eğitim Fakültesi Dergisi, 8(1), 137-159.

Panasan, M., \& Nuangchalerm, P. (2010). Learning outcomes of project-based and inquiry-based learning activities. Journal of Social Sciences, 6(2), 252-255.

Partnership for 21 st Century Skills. (2009). P21 framework definitions. Retrieved from http://www.p21.org/storage/ documents/P21_Framework_Definitions.pdf

Saracaloğlu, A.S. ve Çelik, B. (2018). Web tasarımı ve programlama dersi öğretiminde proje tabanlı öğrenme yaklaşımı kullanımının öğrenci görüşlerine göre değerlendirilmesi. Kastamonu Education Journal, 26(2), 323-333.

Sokur, E. (2018). Proje tabanl öğrenme yaklaşımına dayalı öğretimin 7.sinlf öğrencilerinin çevre konusundaki başarılarına ve kavramsal anlamalarına etkisinin ögrenme stillerine göre incelenmesi. Yüksek Lisans Tezi, Marmara Üniversitesi, Eğitim Bilimleri Enstitüsü, İstanbul.

Trilling, B., \& Fadel, C. (2009). 21 st Century Skills: Learning for Life in Our Times. San Francisco, CA: John Wiley \& Sons. 
Tompkins, P., \& Lawley, J. (2002). The magic of metaphor. The Caroline Newsletter, March.

Uzal, G., Erdem, A. ve Ersoy, Y. (2012). Proje tabanlı fen/matematik eğitimi projesinden yansıtmalar-II: Kazanılan yeterlikler ve öğretmen görüşleri. X. Ulusal Fen Bilimleri ve Matematik Ĕ̆itimi Kongresi, Niğde.

Velegol, S. B., Zappe, S. E., \& Mahoney, E. (2015). The evolution of a flipped classroom: Evidencebased recommendations. Advances in Engineering Education, 4(3), 1-17.

Weber, M. (2019). The Importance of Collaboration Within Project-Based Learning in a Kindergarten Teacher Classroom. Masters Theses/Capstone Projects, Otterbein University, Westerville, Ohio.

Wu S., \& Meng, L. (2010). The integration of inter-culture education into intensive reading teaching for english majors through project-based learning. US China Foreign Lang 8(10), 26-37.

Yıldırım, A. ve Şimşek, H. (2013). Sosyal bilimlerde nitel araştırma yöntemleri (9. Baskı). Ankara: Seçkin Yayıncılık.

Yıldız İ. ve Uyanık N. (2004). Matematik eğitiminde ölçme değerlendirme üzerine. Gazi Üniversitesi Kastamonu Ĕ̆itim Dergisi, 12(1), 97-104.

Zelyurt, H. ve Özbek, R. (2018). Teachers' views about alternative assessment tools. Inonu University Journal of the Faculty of Education, 19(2), 370-396.

Zimbicki, D. (2007). Examining the effects of alternative asessment on student motivation and self efficancy. Doctoral Dissertation, The Walden University, U.S.A. 


\section{Extended Abstract}

\section{Introduction}

Alternative assessment and evaluation methods offer students multiple evaluation environments where they can display their skills, knowledge and attitudes (Ari, 2010; Ministry of National Education, 2018). In addition, these methods help students express their thoughts confidently (Yildiz \& Uyanik, 2004) and pave the way for measuring affective and high-level skills (Hodges et al., 2005). Examples to alternative assessment and evaluation methods and techniques are; self-evaluation, student product files, peer evaluation, control lists, grading scales, structured grid, poster, performance, and project studies (Egodawatte, 2010). Among these alternative assessment and evaluation methods; project studies, which give students an opportunity of reaching new information and presenting the information and gain critical and creative thinking skills in the solution of daily life problems, have an important place in today's system of education. One of the primary lessons in which project studies are used intensely is science lesson (Sokur, 2018).

In science lesson, project studies are of prime importance for including students in the process and realizing permanent learning. In order to do that, a great role falls to teachers. However, it is seen that teachers face many difficulties throughout their project assignment (Bayat \& Senturk, 2015). For example, it is stated that teachers face problems in assigning students to an appropriate project task, managing the project process, creating student groups, reporting projects, guiding students, and evaluating the project task (Akbas \& Gencturk, 2013; Oztuna Kaplan \& Diker Coskun, 2012; Uzal, Erdem \& Ersoy, 2012). In this context, it is recommended to provide necessary trainings to teachers who face problems in alternative assessment and evaluation processes (Neukom, 2000; Zimbicki, 2007). Additionally, upon the literature review, we have encountered no study analyzing the perceptions of especially science teachers concerning project studies. Thus, the perceptions of science teachers concerning project studies, which are one of effective ways in bringing the 21st century skills in students, are important for students to develop a scientific viewpoint (Onen-Ozturk \& Aglarci, 2019) and in the first section of the study, it is tried to reveal metaphoric perceptions of the teachers concerning the concept of project. Also, it is seen that there is a limited number of studies determining the problems faced by science teachers during project studies and evaluating teachers' solution offers to these problems (Coruhlu, Er Nas \& Cepni, 2009). In this section of the study, on the other hand, the views of the science teachers on the advantages of project studies they guide, difficulties they face in project studies and solution offers were examined. Thus, through this study, it will be possible to examine the science teachers' project perceptions, problems they face in project studies, and their solution offers. It is believed that the results will contribute to science teachers who use project studies in their lessons intensely, to students who conduct project studies in the field of science and to researchers who intend to conduct researches in this field. From this point of view, answers were sought to the following problems:

- What are the metaphors expressed by science teachers concerning the concept of project? Under what conceptual categories can these metaphors be expressed in terms of common properties?

- What are the views of science teachers on the advantages of project studies?

- What are the problems faced by science teachers in the process of project studies? 
- What are the solution offers of science teachers to the problems faced in the process of project studies?

\section{Method}

The study was conducted using case study, which is among qualitative research method designs. Sample group of the study consisted of 82 science teachers working in different districts and schools of the province of Malatya in the school year of 2018-2019. A metaphor form and a written view questions form were used as data collection tool. The form used in the study consists of two sections. While the first section includes demographic information of the participants, the second section includes a metaphor statement aiming to determine the project perceptions of the participants and three open-ended questions to express their opinions about project studies. Content analysis method was used in the analysis of the data.

\section{Result}

It was determined that the 82 science teachers who participated in the study produced 68 metaphors concerning the concept of project. As a result of the content analysis, the metaphors determined by the science teachers and included in the study were collected under six conceptual categories as "aiding in learning, endeavoring, design, process, source of happiness, and unnecessary/useless". In addition, it is seen that the science teachers produced the highest number of metaphors under the category of "aiding in learning" (30.89\%) and the lowest number of metaphors under the category of "unnecessary/useless" and "source of happiness" (8.82\%). After revealing the perceptions of the teachers concerning the concept of project via metaphors, the teachers were asked, "What do you think about the advantages of project studies (homework) you guide in your school?". In this context, it was seen that most of the teachers stated that project studies increased the sense of curiosity and investigation concerning the benefits of the project studies (19.51\%). Additionally, the teachers stated that they faced the problems mostly at the point of accessing to data collection tool in project studies (24.39\%). An important part of the teachers $(43.90 \%)$ stressed the necessity of placing importance to guidance studies in order to make students like project studies and obtain the desired efficiency in project studies.

\section{Discussion}

In the study, it was aimed to evaluate the project perceptions of science teachers and their views on project studies they guided. In this context, the study was conducted with 82 science teachers who were experienced in guiding project studies. First of all, the metaphor form was used for examining the perceptions of the science teachers concerning the concept of project and it was determined that the teachers in the sample produced 68 metaphors (Table 2). In addition, it was determined that 14 teachers had a difficulty in producing metaphors, which shows that the teachers did not have sufficient perceptions concerning the concept of project. It is recommended to enhance the perceptions of science teachers concerning project studies, which are one of the most effective ways of bringing the 21 st century skills in students, and to emphasize project studies throughout their undergraduate study in order to prevent their negative perceptions. 